\title{
Rancang Bangun Pengamanan FTP Server dengan Menggunakan Secure Sockets Layer
}

\author{
Molavi Arman \\ AMIK MDP \\ Manajemen Informatika \\ Jalan Rajawali No.14, Palembang, Indonesia \\ e-mail: molavi.arman@mdp.ac.id
}

\begin{abstract}
Abstrak
Teknologi informasi yang berkembang pesat didalam kehidupan manusia, membuat kebutuhan akan sistem penyimpanan data terpusat menjadi sesuatu yang penting dalam penyimpanan arsip digital. Data tidak hanya disimpan dalam sebuah personal computer desktop tetapi media penyimpanan data terpusat menjadi alternatif dalam media penyimpanan, guna menjaga dari kehilangan data atau backup data.

Teknologi jaringan (network) komputer merupakan solusi yang dapat dimanfaatkan untuk memenuhi penyimpanan data. Jaringan komputer merupakan kumpulan beberapa komputer dan perangkat jaringan lain yang saling terhubung melalui media perantara.

FTP (File Tranfer Protocol) umumnya berfungsi sebagai media tukar menukar file atau data dalam suatu network yang menggunakan koneksi TCP. Protokol FTP tidak cukup aman dikarenakan pada saat autentifikasi output karakter berupa plaintext dan disaat transfer data tidak ada enkripsi untuk melindungi. Protokol FTP butuh penambahan keamanan, dengan menggunakan protokol TLS (Transport Layer Security) dan Auth SSL untuk mengamankan protokol FTP pada saat autentikasi dan proses transfer data.

Untuk melindungi FTP server dari kerentanan autentikasi dan pengiriman data perlu ditambahkan fitur keamanan menggunakan Secure Sockets Layer (SSL) untuk mengenkripsi protokol FTP pada saat autentikasi dan proses transfer data. Sertifikat SSL digunakan untuk menangani keamanan pada paket data yang ditransmisikan melalui jaringan. Ketika SSL digunakan, maka server atau penyedia jasa akan memberikan sertifikat publik ke klien untuk melakukan autentikasi keabsahan identitas dari server. Ketika sudah terautentikasi, maka koneksi antara server dengan klien akan dienkripsi.
\end{abstract}

Kata Kunci: Kinerja FTP, Jaringan Komputer, Database, PHP, TLS, SSL.

\begin{abstract}
The rapid development of information technology in human life makes the need of centralized data storage system become an important thing in digital archives storage. The data is not only stored in personal computer desktop but also protected to keep the data or data back up.

Computer network technology is a solution that can be used to save the data. Computer network is a group of computers and other network device connected to each other through media.

FTP (File Transfer Protocol) generally functions as media to transfer file or data in a network using TCP connection. FTP protocol is not secure enough since during the authentication the character of the output is in the form of plaintext and during data transfer there is no encryption to protect. FTP protocol needs additional security using TLS (Transport Layer Security) and Auth SSL to secure FTP protocol during authentication and data transfer process.

To protect FTP server from the authentication susceptibility and data transfer, security feature using Secure Socket layer (SSL) should be added to encrypt FTP protocol during authentication and data transfer. SSL certifícate is used to handle the security of data packet transmitted through the network. When SSL is used, server will give public certifícate to the client to do authentication of identity from the server. After being authenticated, the connection between server and client will be encrypted.
\end{abstract}

Keywords: FTP, Computer Network, Database, PHP, TLS, SSL. 


\section{Pendahuluan}

Teknologi informasi yang berkembang pesat didalam kehidupan manusia, membuat kebutuhan akan sistem penyimpanan data terpusat menjadi sesuatu yang penting dalam penyimpanan arsip dan dokumen digital. Data tidak hanya disimpan dalam sebuah $\mathrm{p} c$ desktop atau media penyimpanan saja tetapi media penyimpanan data terpusat menjadi alternative dalam media penyimpanan, guna menjaga dari kehilangan data atau backup data.

Teknologi Jaringan (network) komputer merupakan solusi yang dapat dimanfaatkan untuk memenuhi penyimpanan data. Jaringan komputer merupakan kumpulan beberapa komputer (dan perangkat lain seperti: printer, hub dan switch dan sebagainya) yang saling terhubung satu sama lain melalui media perantara. Jadi dengan adanya jaringan komputer tersebut penyimpanan data terpusat dapat dilakukan dengan baik.

FTP (File Tranfer Protocol) umumnya berfungsi sebagai media tukar menukar file atau data dalam suatu network yang menggunakan TCP koneksi. FTP yang digunakan menggunakan berbasis Open Source guna menunjang tingkat stabilitas tinggi dan tidak mudah terinfeksi virus dan malware. FTP merupakan metode protokol pilihan yang paling tepat dalam penyimpanan file/data secara cepat dalam proses upload dan download dari komputer server ke klien tanpa menggunakan flashdisk untuk mengambil data dari komputer server.

Protokol FTP tidak didisain secara aman , FTP memiliki kelemahan dan kendala dalam autentikasi serta pengiriman data dari server ke klien atau sebaliknya, kelemahan inilah cukup membahanyakan jika digunakan pihak-pihak tertentu untuk melakukan penyadapan akun dan data dijaringan.[1]

Untuk melindungi FTP server dari kerentanan autentikasi dan pengiriman data perlu ditambahkan fitur keamanan menggunakan Secure Sockets Layer (SSL) untuk mengenkripsi protokol FTP pada saat autentikasi dan proses transfer data. Sertifikat SSL digunakan untuk menangani keamanan pada paket data yang ditransmisikan melalui jaringan. Ketika SSL digunakan, maka server atau penyedia jasa akan memberikan sertifikat publik ke klien untuk melakukan autentikasi keabsahan identitas dari server. Ketika sudah terautentikasi, maka koneksi antara server dengan klien akan dienkripsi.

Penerapan ini menggunakan $M y S Q L$ yang difungsikan sebagai database untuk menyimpan user dan profile besarnya quota yang diberikan. Jumlah karyawan yang banyak, hal ini sangat menyulitkan jika harus menambahkan user sercara manual didalam sistem.

Proses memasukkan user, quota secara manual kedalam sistem dan menyangkut soal keamanan autentikasi serta transfer data, dengan penjelasan kendala diatas maka tema yang diambil berupa
Racang Bangun Pengamanan FTP Server dengan Menggunakan Protocol SSL (Secure Sockets Layer).

\section{Dasar Teori}

\subsection{FTP (File Transfer Protocol)}

File Transfer Protocol (FTP) merupakan client / server protokol yang menyediakan fasilitas untuk transfer data dalam jaringan atau dengan kata lain protokol yang digunakan untuk pertukaran file antara dua host dalam jaringan TCP/IP. Sebuah FTP server dapat diset sebagai FTP publik sehingga setiap orang dapat mengakses data-data yang ada di server FTP dengan menggunakan login anonymous atau FTP. Selain itu, FTP juga dapat di-set agar server hanya dapat diakses oleh user tertentu saja dan tidak untuk public [2].

\subsection{SSL (Secure Sockets Layer)}

OpenSSL dan TLS (Transport Layer Security) merupakan protokol kembar yang digunakan untuk menangani keamanan paket data yang ditransmisikan melalui jaringan. Kedua protokol tersebut dikembangkan oleh Netscape. Ketika SSL digunakan, maka server atau penyedia jasa akan memberikan sertifikat publik ke klien dan melakukan autentikasi keabsahan indentitas dari server. Ketika sudah terautentikasi, maka koneksi antara server dengan klien akan dienkripsi. OpenSLL, merupakan aplikasi yang menghasilkan sertifikat SSL. Aplikasi ini akan digunakan oleh server untuk mengamankan koneksi tersebut [3].

\subsection{PHP dan Apache}

PHP adalah suatu bahasa pemrograman web open source yang digunakan secara luas terutama untuk mengembangkan web dan dapat disimpan dalam bentuk HTML. PHP dirilis pada tanggal 13 Juli 2004. PHP 5 dapat digunakan hampir semua sistem operasi utama, seperti Linux, varian UNIX (Mencakup HPUX, Solaris dan OpenBSD), Microsoft Windows, Mac OSX. PHP juga mendukung hampir semua web server. PHP digunakan untuk memudahkan pengimputan nilai dalam bentuk web base [4].

Aplikasi web server yang cukup terkenal dan banyak digunakan adalah Apache yang tersedia untuk banyak sistem operasi. Hal ini dikarenakan sifat Apache yang dibangun dengan sistem modul sehingga kemampuan Apache dapat dikembangkan lebih jauh lagi. Webserver Apache yang digunakan adalah versi httpd-2.4.25.

\subsection{Database MariaDB}

Database adalah tempat menyimpan informasi. Memungkin untuk seseorang dengan mudah merekam dan kemudian mengakses sejumlah besar informasi untuk berbagai tujuan. Hampir semua jenis data dapat disimpan dalam database. Database dapat penyimpan nama dan alamat, catatan medis, laporan polisi, 
transaksi penjualan, informasi tentang musik dan video koleksi, dan banyak lagi [5].

Untuk rancang bangun ini menggunakan MariaDB sebagai database, fungsi MariaDB dalam rancang bangun disini adalah menyimpan nama user dan besaran kapasitas quota yang digunakan untuk masing masing user.

\section{Metodologi Penelitian}

Teknik pengerjaan sebagai berikut:

a. Menyiapkan Kebutuhan

Kebutuhan yang disiapkan adalah yang berhubungan dengan rancang bangun protokol FTP server, protokol ssl, database MariaDB, Apache dan modul PHP.

b. Analisis Kebutuhan

Sistem FTP server yang akan dirancang bangun dengan autentikasi user name, password serta dikombinasikan dengan SSL dan tempat penyimpanan hard drive dengan disk kuota yang diintegrasikan dengan MariaDB.

c. Perancangan Sistem

Perancangan sistem ini dengan menerapkan FTP server dengan SSL dan pembatasan kuota pada tiap user-nya dengan MariaDB sebagai database. Pemilihan sistem operasi yang digunakan pada server dan klien serta perangkat lunak aplikasi yang akan digunakan.

d. Implementasi dan Pengujian

Rancang bangun dan pengujian FTP server dengan SSL guna keamanan saat autentikasi serta transfer data dan ditambah disk kuota pada user yang di integrasikan pada tampilan web base supaya memudahkan pengisian besarnya kapasitas pada user. Pengujian pada transfer data menggunakan file dengan format teks yang akan disadap dan berhasil dibaca dengan tools jaringan wireshark. Pada pengujian disk kuota dilakukan pembatasan kapasitas pada tiap user dan dilakukan upload file teks tersebut dengan menggunakan FTP klien yaitu FileZilla yang menandakan user tersebut berhasil melakukan upload.

e. Pembuatan Pelaporan

Penyusunan pelaporan mengumpulkan dokumentasi dengan mengikuti format yang baik dan benar yang telah ditetapkan. [6]

\section{Analisis, Perancangan Dan Implementasi Pengujian}

\subsection{Analisa Kebutuhan Hardware Dan Software}

Kebutuhan hardware dalam rancang bangun ini perangkat keras yang digunakan adalah sebagai berikut:

a. PC dengan spesifikasi processor AMD Bulldozer sebagai server FTP.

b. Memori $8 \mathrm{~GB}$.

c. Hard Drive 500GB.

d. Monitor, keyboard, mouse, switch 8 port dan kabel jaringan UTP

Kebutuhan software agar penelitian ini berjalan semestinya dibutuhkan beberapa software yang mendukung diataranya sebagai berikut:

a. Komputer FTP server menggunakan sistem operasi Linux.

b. FTP server menggunakan aplikasi Proftpd.

c. FTP client menggunakan aplikasi FileZilla.

d. Database menggunakan MariaDB, simpan nama user dan besaran kuota.

e. Aplikasi sniffing menggunakan wireshark.

f. Untuk pembuatan sertifikat SSL menggunakan OpenSSL.

g. Web server Apache menjalankan script php.

h. Bahasa pemrograman menggunakan bahasa php.

\subsection{Analisa Perancangan / Kebutuhan Sistem}

Kebutuhan sistem adalah suatu proses yang akan mengidentifikasi dan melakukan evaluasi terhadap permasalahan, dengan identifikasi dan evaluasi sehingga dibangun sistem yang sesuai. Rancang bangun pengamanan FTP server yang akan dibangun ada analisis kebutuhan, berikutnya yaitu:

a. FTP server menggunakan autentikasi untuk melindungi dan mengamani berkas atau file yang disimpan.

b. Implementasi ssl untuk melindungi proses autentifikasi, transfer data dari FTP Client menuju FTP server atau sebaliknya dan membatasi kuota.

c. Kuota yang dibatasi untuk setiap user yang terdaftar didalam database.

\subsection{Topologi yang Akan dibangun}

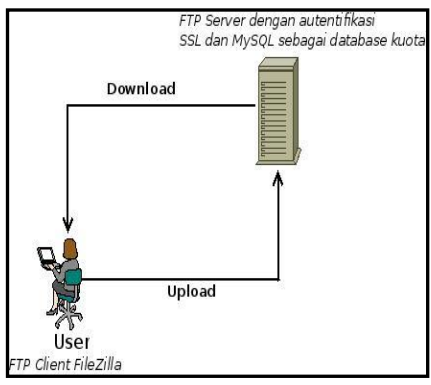

Gambar 1. Topologi yang akan dibangun

FTP server yang akan dibangun untuk pembuatan nama user, password dan kapasistas kuota untuk setiap user akan menggunakan web base. User yang akan melakukan download dan upload pada FTP server tanpa autentikasi ssl user dan password tidak akan terlindungi karena sifatnya plaintext. Pada FTP 
server dengan autentikasi SSL nama user, password dan data yang berjalan didalam network upload maupun download akan terlindungi oleh sertifikat SSL.

\subsection{Alur Rancang FTP Server}

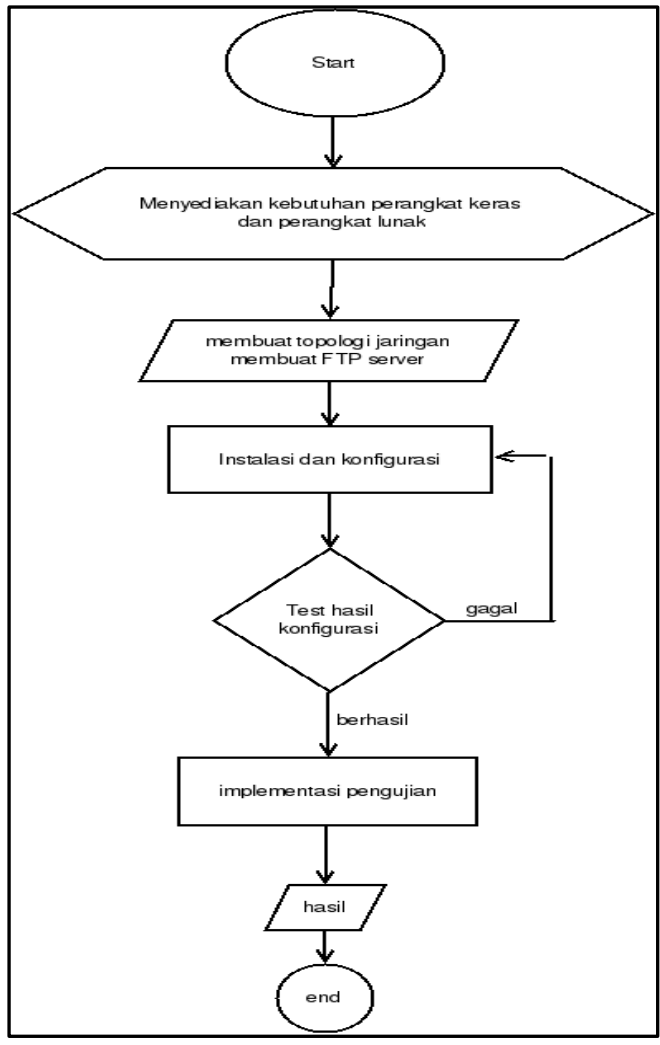

Gambar 2. Alur Rancang Bangun FTP Server

\subsection{Perancangan FTP Server}

Perancangan FTP Server ini menggunakan pengamanan user dan password. Pada saat user name dan password dibuat kemudian digunakan untuk login ke FTP server otomatis direktori tempat meletakkan berkas atau dokumen akan tercipta dengan sendirinya berbarengan pada saat login. User pada FTP server hanya bisa mengakses direktori user tersebut dan tidak bisa mengakses hak user lain tanpa mengetahui user name dan passwordnya.

\subsection{Perancangan FTP Server dengan Secure Sockets Layer}

Perancangan File Transfer Protocol Server yang dikombinasikan dengan Secure Sockets Layer digunakan untuk menambahkan proses pengamanan dibandingkan dengan FTP server secara default system. Maksud dari menambahkan pengamanan disini adalah user name, password dan paket data dilindungi oleh sertifkat ssl yang telah dikombinasikan dengan FTP server, sehingga terlindungi dari kegiatan sniffing didalam jaringan.

\subsection{Perancangan Database dan Script PHP}

Database menggunakan MariaDB dan script pemrograman php, maksudnya adalah untuk memudahkan proses pembuatan nama user, password dan ukuran kuota yang diberikan pada masing-masing user dalam bentuk interface web base. Komponen yang akan diisikan seperti, user, password, kuota dan user id.

\subsection{Alat Uji}

Untuk pengujian dan pembuktian keamanan protokol FTP dan FTPS menggunakan sebuah aplikasi yaitu wireshark atau ethereal. Wireshark adalah adalah aplikasi komputer packet sniffer yang bersifat free. Hal ini digunakan untuk mengatasi masalah jaringan, analisis, pengembangan perangkat lunak dan protokol komunikasi, dan pendidikan. Pada bulan Juni 2006, proyek ini berganti nama dari Ethereal karena masalah merek dagang. [7]

Fungsionalitas Wireshark sangat mirip dengan tcpdump, tetapi memiliki grafis front-end dan banyak informasi lebih lanjut menyortir dan penyaringan pilihan. Hal ini memungkinkan pengguna untuk melihat semua lalu lintas yang melewati jaringan (biasanya jaringan Ethernet namun dukungan yang ditambahkan untuk orang lain) dengan menempatkan antarmuka jaringan ke modus promiscuous. [8]

\subsection{Instalasi Aplikasi MariaDB dan phpMyadmin}

Database yang digunakan penulis adalah MySQL, aplikasi bantuan adalah phpMyadmin yang berjalan pada web server Apache untuk memudahkan manajemen pada database MariaDB. Langkah instalasi adalah sebagai berikut:

Tabel I

Perintah instalasi MariaDB, phpMyAdmin dan Apache

\# apt-get install mariadb-server phpmyadmin apache2

\subsection{Pemasangan Perangkat Lunak Proftpd dan Dukungan MariaDB}

Sebelum melakukan instalasi aplikasi terlebih dahulu melakukan instalasi sistem operasi Ubuntu 14.10 64bit pada komputer server. Setelah instalasi selesai dilanjutkan dengan instalasi FTP server berupa aplikasi proftpd dan dukungan database yaitu MariaDB. Perintah instalasi adalah sebagai berikut:

\section{Tabel II}

Instalasi Proftpd dengan modul MariaDB

\# apt-get install proftpd-mod-mysql

Kemudian langkah berikutnya membuat group FTP (ftpgroup) dan pengguna (ftpuser) bahwa semua pengguna virtual akan dipetakan menggantikan kelompok dan userid 2001 dengan nomor yang bebas di sistem. 
Tabel III

Membuat group dan user

\# groupadd - 2001 ftpgroup

\# useradd - 2001 -s /bin/false -d /bin/null -c "proftpd user" - $g$ ftpgroup ftpuser

\subsection{Membuat Database}

Tahap ini untuk mengintegrasikan komponen Proftpd sebagai FTP server dengan memasukkan kedalam database seperti user, password, kapasitas kuota, userid dan lainnya. Langkah perintah pembuatan komponen database proftpd sebagai berikut :

\section{Tabel IV}

Membuat database FTP

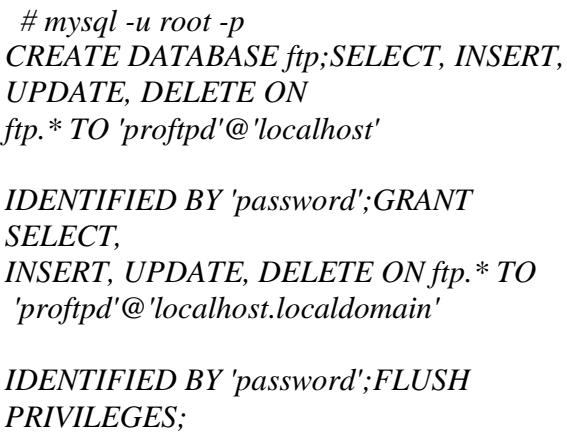

Tabel V

Membuat Table ftpgroup dan ftpquotalimits

USE ftp;

CREATE TABLE ftpgroup (groupname

varchar(16)

NOT NULL default ", gid smallint(6) NOT

NULL

default '5500',members varchar(16) NOT

NULL default ", KEY groupname

(groupname))

ENGINE $=$ MyISAM COMMENT $=$ 'ProFTP

group table':

CREATE TABLE ftpquotalimits (name varchar(30) default

NULL,quota type enum('user','group' ,'class', 'all') NOT NULL default 'user' ,per_session enum('false','true') NOT $N U L L$

default 'false',limit_type enum('soft','hard')

NOT NULL default 'soft',bytes_in avail

bigint(20) Unsigned NOT NULL

default 'O',bytes_out_avail bigint(20)

unsigned NOT NULL default ' $O$ ' ,

bytes_xfer_avail bigint (20) unsigned NOT

$N U L L$ default ' $O$ ', files_in_avail int $(10)$

unsigned NOT NULL default ' $O$ ',

files_out_avail int(10) unsigned NOT

NULL default ' $O$ ', files_xfer_avail int(10)

unsigned NOT NULL default ' $O$ ')

ENGINE $=$ MYISAM;
Tabel VI

Membuat ftpquotatallies dan ftpuser

CREATE TABLE ftpquotatallies (name varchar (30) NOT NULL default ",quota_type enum ('user','group','class','all') NOT NULL default 'user',bytes_in_used bigint(20) unsigned NOT NULL default ' 0 ', bytes_out_used bigint(20) unsigned NOT NULL default ' $O$ ',

bytes_xfer_used bigint(20) unsigned NOT NULL default ' $O$ ',files_in_used int (10) unsigned NOT NULL default 'O',files_out_used int(10) unsigned NOT NULL default ' 0 ', files_xfer_used int(10) unsigned NOT NULL default ' $O^{\prime}$ ) ENGINE $=$ MyISAM;

CREATE TABLE ftpuser (id int(10) unsigned NOT NULL auto_increment, userid varchar (32) NOT NULL default ",passwd varchar (32) NOT NULL default ", uid smallint(6) NOT NULL default '5500', gid smallint(6) NOT NULL default '5500', homedir varchar (255) NOT NULL default ", shell varchar (16) NOT NULL default '/sbin/nologin', count int (11) NOT NULL default ' 0 ', accessed datetime NOT NULL default '0000-00-00 00:00:00',modified datetime NOT NULL default

'0000-00-00 00:00:00',PRIMARY KEY

(id), UNIQUE KEY userid (userid)) ENGINE= MYISAM COMMENT='ProFTP user table'; quit;

\subsection{Konfigurasi Proftpd}

Melakukan editing pada file modules.conf, dengan mengaktifkan beberapa fitur [9], perintahnya sebagai berikut:

Tabel VII

Perintah edit modules.conf

\# nano /etc/proftpd/modules.conf

LoadModule mod_sql.c

LoadModule mod_sql_mysql.c

LoadModule mod_quotatab_sql. 
Dilanjutkan dengan editing file proftpd.conf

Tabel VIII

Mengaktifkan koneksi MySQL di Proftpd

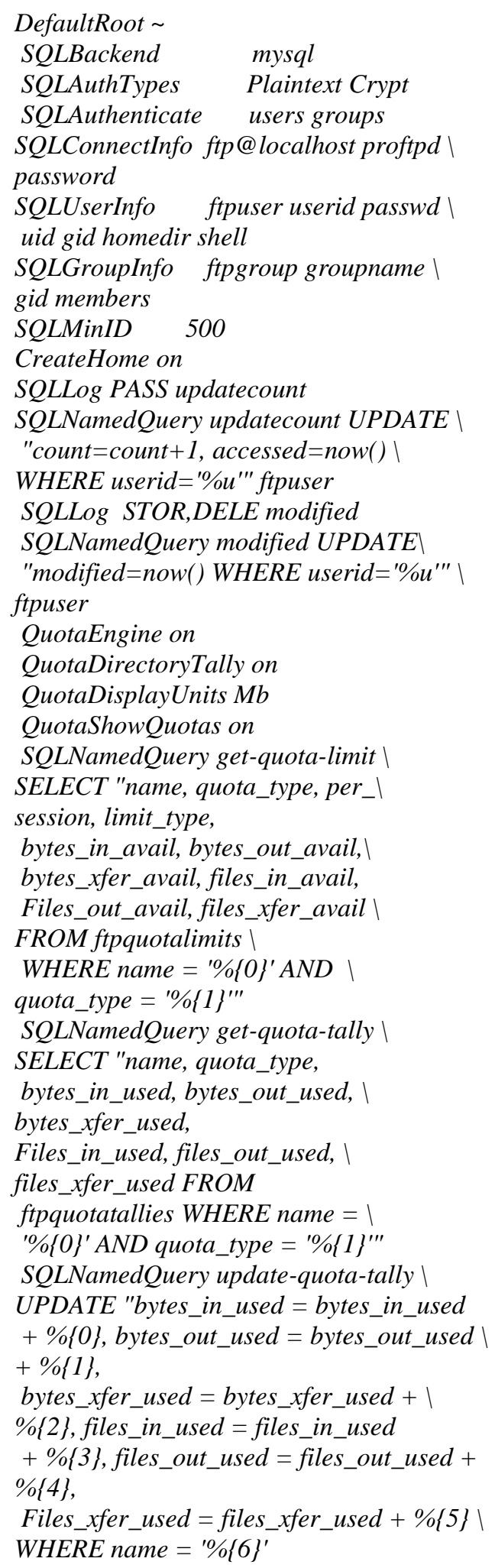

AND quota_type $={ }^{\prime} \%\{7\}^{\prime \prime \prime}$ ftpquotatallies SQLNamedQuery insert-quota-tally $\backslash$ INSERT "\%\{0\}, \%\{1\}, \%\{2\}, \%\{3\}, \%\{4\}, $\%\{5\}, \%\{6\}, \%\{7\} "$ ftpquotatallies QuotaLimitTable sql:/get-quota-limit QuotaTallyTable sql:/get-quota-tally $\backslash$ /update-quota-tally/insert-quota-tally RootLogin off

RequireValidShell off

\subsection{Tahap Pemasangan SSL dan Membuat Sertifikat SSL Untuk TLS (Transport Layer Security)}

Secure Sockets Layer adalah sebagai pelindung otentikasi dan traffic data dari server ke klien maupun sebaliknya. Aplikasi yang digunakanan untuk ssl adalah menggunakan OpenSSL. Perintah instalasi adalah sebagai berikut:

Tabel IX

Perintah instalasi openssl

\# apt-get install openssl

Dilanjutlah dengan membuat sertifikat SSL

Tabel X

Membuat sertifikat SSL

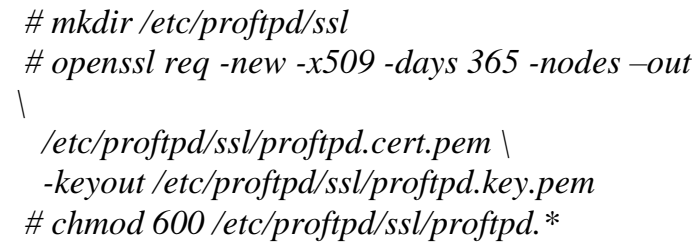

Kemudian adalah mengaktifkan TLS (Transport Layer Security) dengan mengedit file letc/proftpd/proftpd.conf

\section{Tabel XI}

Mengaktifkan TLS pada Proftpd

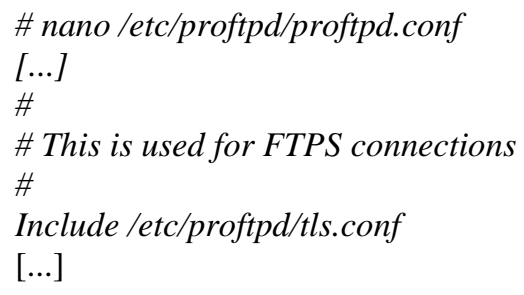

Dilanjutkan dengan mengedit file /etc/proftpd/tls.conf 
Tabel XII

tls.conf

$\langle$ IfModule mod_tls.c>

TLSEngine on

TLSLog /var/log/proftpd/tls.log

TLSProtocol TLSV1.2

TLSCipherSuite AES128+EECDH:AES128+ I

EDH

TLSOptions NoCertRequest

AllowClientRenegotiations

TLSRSACertificateFile letc/proftpd八

ssl/proftpd.cert.pem

TLSRSACertificateKeyFile letc/proftpd八

ssl/proftpd.key.pem

TLSVerifyClient

TLSRequired

off

Require

</IfModule >

\subsection{Tahap Meletakkan Script PHP}

Script program php yang telah dibuat dimasukkan kedalam web server yang telah disediakan, default var/www/html, kemudian tampilan interface sebagai berikut :

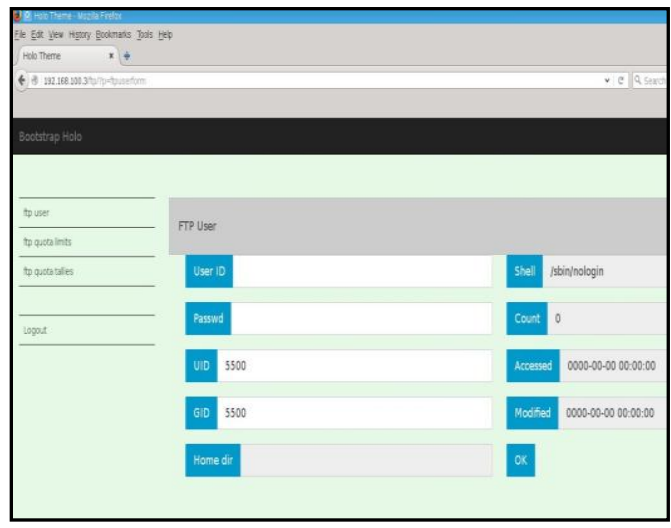

Gambar 3: Interface FTP user

\subsection{Pengujian}

Maksud dari pengujian adalah melindungi proses autentikasi FTP server dengan SSL. Hal yang diuji adalah proses autentikasi FTP server tanpa SSL dan FTP server dengan SSL. Sebagai acuan keberhasilan adalah jika username dan password yang dikirim tidak bisa disadap oleh aplikasi wireshark dan sebagi acuan gagal bilamana username dan password mampu disadap oleh aplikasi wireshark.

Aplikasi FileZila melakukan proses login kedalam FTP server dengan user name arman, password 123456 dan nama file dengan nama berkas.txt isi file AMIK MDP terlihat pada gambar 4.

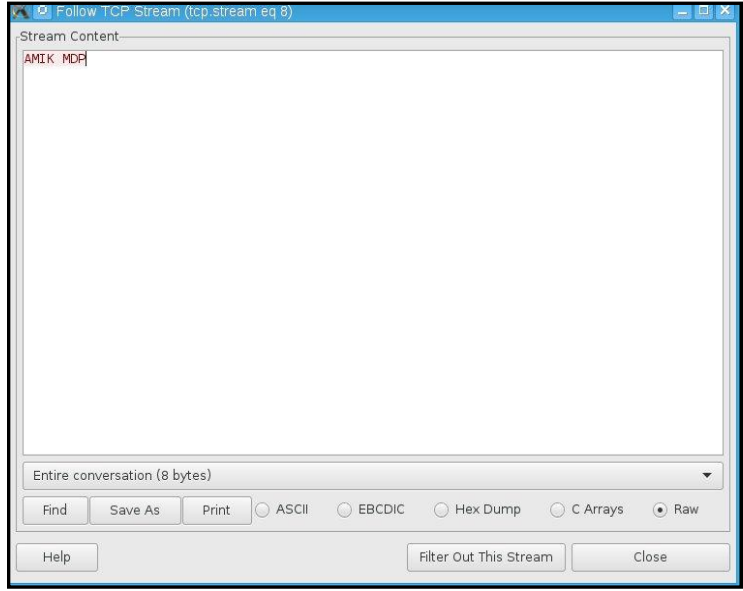

Gambar 4: bukti user dan password

Isi file berkas.txt yang ditangkap oleh aplikasi wireshark terlihat pada gambar 5 .

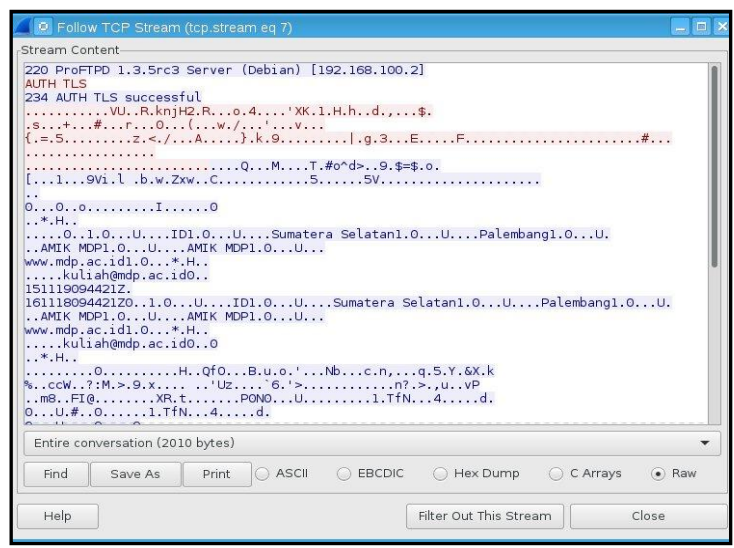

Gambar 5: Bukti isi file berkas.txt

FileZilla melakukan proses login kedalam FTP server dengan sertifikat SSL terlihat pada gambar 6 .

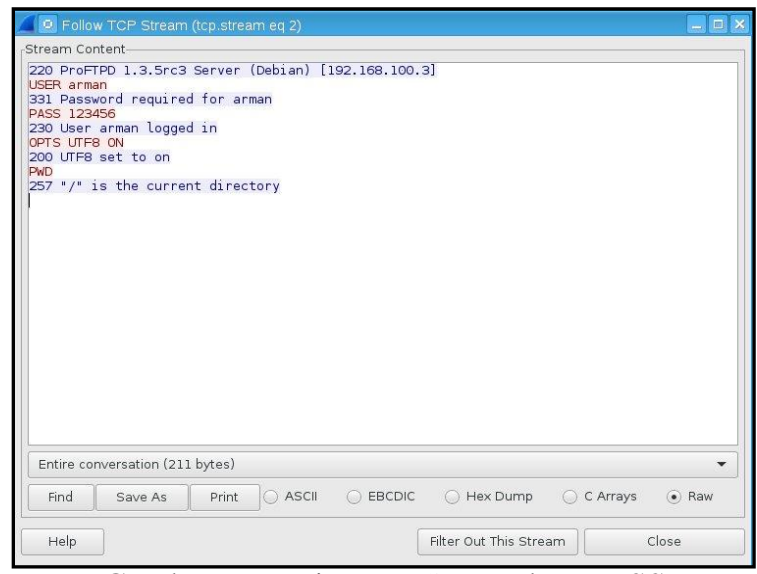

Gambar 6: Login FTP Server dengan SSL

Pada FTP server dengan sertifikat SSL terlihat pada gambar xx bahwa user, password dan file yang diupload tidak terbaca pada aplikasi wireshark. 


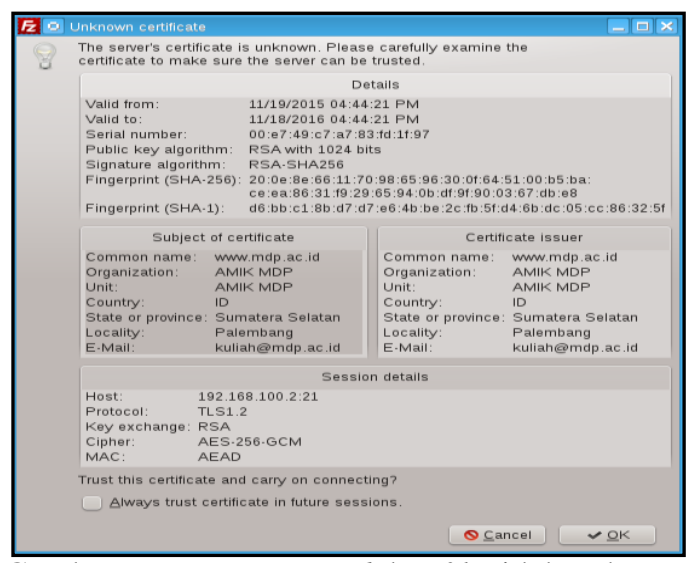

Gambar 7: user, password dan file tidak terbaca

\section{Hasil Penelitian}

Hasil penelitian menunjukkan bahwa:

a. Pada protokol FTP terlihat tidak terdapat pengamanan saat dilakukan penyadapan login username dan password, sehingga dapat diketahui username dan password

b. Pada protokol FTP terlihat pada saat penyadapan transfer data dari client menuju server FTP dengan terlihat isi file tersebut.

c. Pada protokol FTPS cukup aman pada saat login username dan password ditunjukkan pada saat penyadapan tidak terlihat username dan password

d. Pada prookol FTPS cukup aman pada saat transfer data dari client menuju server, ditujukkan tidak terlihat isi dari file yang dikirim

\section{Kesimpulan dan Saran}

\subsection{Kesimpulan}

Kesimpulan yang dapat diambil dalam rancang bangun FTP server ini adalah sebagai berikut:

a. Dalam mengamankan FTP server dalam autentikasi yang masih standar (plaintext) adalah dengan menggunakan protokol ssl

b. FTP Server dalam transfer file tidak aman dengan terbacanya isi file berkas.txt.

c. Dalam perbandingan FTP server tanpa sertifikat ssl dan FTP server dengan sertifikat ssl bahwa menunjukkan FTP server tanpa sertifikat ssl tidaklah aman.

d. Kuota yang sudah dibatasi tidak akan bisa melebihi limit yang telah ditentukan.

\subsection{Saran}

Saran dalam pengembangan kedepan adalah sebagai berikut:

a. Rancang bangun ini dapat dikembangkan dengan mengintegrasikan kedalam alamat DNS, sehingga mudah dalam penamaan tidak perlu lagi mengigat IP Address FTP server.

b. Rancang bangun ini bisa dikembangkan ke akses internet dengan menggunakan IP Address Public serta mengintegrasikan kedalam infrastruktur DMZ.

\section{DAFTAR PUSTAKA}

[1] A.T. Sonale, S.S Matsagar, FTP Security using face recognition \& Dynamic password, IOSR Journal of Computer Engineering, Second International Conference on Emerging Trends in Engineering (SICETE), Vol.1,PP:58-61. India. 2013

[2] Askari Azikin., 2011, Debian Gnu / Linux. Informatika Bandung. Bandung.

[3] Imam Cartealy., 2013, Linux Networking. Jasakom. Jakarta.

[4] Wahana Komputer, 2006, Menguasai Pemrograman Web Dengan PHP 5. Andi Offset. Yogyakarta.

[5] Timothy Boronczyk., 2009, Beginning PHP6, Apache, MySQL Web Development. Willey Publishing. Indianapolis.

[6] Muhammad Martin, Ruswanda, Prajna Deshanta Ibnugraha, Tafta Zani., Implementasi FTP Server Dengan Secure Sockets Layer Dan Secure Shell Untuk Keamanan Transfer Data. Politeknik Telkom Bandung. Bandung. 2011.

[7] Ahmad Fali Oklilas, Budi Irawan, Implementasi FTP Server dengan Metode Transfer Layer Security untuk Keamanan Transfer Data Menggunakan CentOS 5.8. Portal Garuda, Vol 9, No 22014.

[8] Laura Chappell, Wireshark Network Analysis the Official Wireshark Certified Network Analyst Study Guide $2^{\text {nd }}$, Chappel Univerity, 2012.

[9] Srijan., 2015, Virtual Hosting With Proftpd and MySQL. [Online]. Tersedia: https://www.howtoforge.com/virtual-hostingwith-proftpd-and-mysql-incl-quota-on-ubuntu14.04-lts. tanggal akses 10 Agustus 2015. 